Canadian

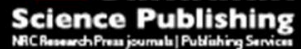

Canadian Journal of Physiology and Pharmacology Revue canadienne de physiologie et pharmacologie

\title{
Syk inhibitor R406 down-regulates inflammation in an in vitro model of Pseudomonas aeruginosa infection
}

\begin{tabular}{|r|l|}
\hline Journal: & Canadian Journal of Physiology and Pharmacology \\
\hline Manuscript ID & cjpp-2017-0307.R1 \\
\hline Manuscript Type: & Article \\
\hline Date Submitted by the Author: & 22-Sep-2017 \\
\hline $\begin{array}{r}\text { Complete List of Authors: } \\
\text { Is the invited manuscript for } \\
\text { consideration in a Special } \\
\text { Issue?: }\end{array}$ & $\begin{array}{l}\text { Alhazmi, Alaa; Lakehead University, Department of Biology } \\
\text { Llanova, Marina; Northern Ontario School of Medicine, Medical Sciences; }\end{array}$ \\
\hline Keyword: & $\begin{array}{l}<\text { i>Pseudomonas aeruginosa </i>, Syk, small molecule inhibitor, R406, } \\
\text { inflammation }\end{array}$ \\
\hline \multicolumn{2}{|c}{} \\
\hline
\end{tabular}

\section{SCHOLARONE \\ Manuscripts}


1 Syk inhibitor R406 down-regulates inflammation in an in vitro model of Pseudomonas aeruginosa infection

$7 \quad{ }^{1}$ Department of Biology, Lakehead University, ${ }^{2}$ Northern Ontario School of Medicine, Thunder

8 Bay, Ontario, Canada

$10 *$ Corresponding Author

11 Address:

12 Professor Marina Ulanova, $\mathrm{MD}, \mathrm{PhD}$

13 Division of Medical Sciences

14 Northern Ontario School of Medicine

15 Lakehead University

16 MS-3006, 955 Oliver Road

17 Thunder Bay, ON P7B 5E1

18 E-mail: mulanova@nosm.ca

19 Tel: 807-766-7340 Fax: 807-766-7362

20 


\section{Abstract}

22 As Pseudomonas aeruginosa infections are characterized by strong inflammation of infected

23 tissues anti-inflammatory therapies in combination with antibiotics have been considered for the

24 treatment of associated diseases. Syk tyrosine kinase is an important regulator of inflammatory

25 responses, and its specific inhibition was explored as a therapeutic option in several inflammatory

26 conditions; however, this has not been studied in bacterial infections. We used a model of in vitro

27 infection of human monocytic cell line THP-1 and lung epithelial cell line H292 with both wild

28 type and flagella-deficient mutant of $P$. aeruginosa strain $\mathrm{K}$, as well as with clinical isolates from

29 cystic fibrosis patients, to study the effect of a small molecule Syk inhibitor R406 on

30 inflammatory responses induced by this pathogen. One-hour long pretreatment of THP-1 cells

31 with $10 \mu \mathrm{M}$ R406 resulted in a significant down-regulation of the expression of the adhesion

32 molecule ICAM-1, pro-inflammatory cytokines TNF $\alpha$ and IL-1 $\beta$, and phosphorylated signaling

33 proteins ERK2, JNK, p-38, and IKB $\alpha$, as well as significantly decreased TNF- $\alpha$ release by

34 infected H292 cells. The results suggest that Syk is involved in the regulation of inflammatory

35 responses to $P$. aeruginosa, and R406 may potentially be useful in dampening the damage caused

36 by severe inflammation associated with this infection.

38 Key Words: Pseudomonas aeruginosa, cystic fibrosis, Syk, small molecule inhibitor, R406,

39 inflammation, cytokine

40

41 


\section{Introduction}

43 Pseudomonas aeruginosa is the major cause of chronic pulmonary infection in cystic fibrosis

44 (CF) patients as well as of other serious conditions in immunocompromised individuals (Saiman

45 and Siegel 2004; Hakki et al. 2007; Crouch Brewer et al. 1996; Lieberman and Lieberman 2003).

46 P. aeruginosa is a Gram-negative opportunistic pathogen armed with potent virulence factors

47 including the type III secretion and quorum sensing systems, lipopolysaccharide, several powerful

48 exotoxins, and various enzymes that contribute to disease pathogenesis via severe tissue damage

49 and inflammation as well as immune evasion (Kipnis 2006). As P. aeruginosa infection is

50 characterized by exaggerated inflammatory responses, anti-inflammatory therapy is considered

51 important for treatment of P. aeruginosa-associated conditions (Cheng et al. 2013). In particular,

52 intracellular protein kinases involved in the regulation of pro-inflammatory signaling pathways

53 may represent potential therapeutic targets. We have recently found that an inhibitor of Syk

54 tyrosine kinase piceatannol is able to down-regulate inflammatory responses in $P$. aeruginosa-

55 infected lung epithelial cells (Aval et al. 2013). However, the effect of piceatannol in this model

56 extended beyond inhibition of Syk, i.e. via potential modulation of Syk-independent signaling

57 pathways (Aval et al. 2013). A small molecule inhibitor, N4-(2,2-dimethyl-3-oxo-4H-

58 pyrid[1,4]oxazin-6-yl)-5-fluoro-N2-(3,4,5-trimethoxyphenyl)-2,4-pyrimidinediamine (R406) was

59 demonstrated to selectively inhibit Syk kinase activity in an ATP-competitive manner both in

60 vitro and in vivo (Cha et al. 2006; Braselmann et al. 2006; Spalton et al. 2009; McAdoo and Tam

61 2011). R406 is the active metabolite of an orally available drug Fostamatinib, which had

62 undergone several clinical trials for treatment of some autoimmune and allergic diseases and

63 hematological malignancies (Riccaboni et al. 2010). However, it is unknown whether R406 can

64 modulate inflammatory responses in infections. In this study, we sought to assess the effect of

65 R406 on inflammatory markers associated with P. aeruginosa infection of human monocytic and

66 lung epithelial cells.

67 


\section{Cell culture conditions}

71 The THP-1 human acute monocytic leukemia cell line (ATCC, Manassas, VA) was used at the

72 passage numbers of 6-20. These cells were maintained in RPMI 1640 medium (Sigma-Aldrich,

73 Oakville, ON, Canada) supplemented with $10 \%$ heat inactivated fetal bovine serum (FBS) (SAFC

74 Biosciences, Lenexa, KS) and 1\% antibiotic-antimycotic (Invitrogen, Burlington, ON, Canada).

75 Cells were grown at $37^{\circ} \mathrm{C}$ with $5 \% \mathrm{CO}_{2}$ and seeded every 3-4 days when cell counts neared $1 \times 10^{6}$

76 cells $/ \mathrm{mL}$. In preparation for experiments, the cells were centrifuged at $400 \times \mathrm{g}$ for 5 minutes,

77 washed with sterile PBS ( $\mathrm{pH}$ 7.4), and suspended in culture medium without antibiotics. To

78 induce differentiation, THP- 1 cells were plated at $1 \times 10^{6}$ cells $/ \mathrm{mL} /$ well in 24 -well plates (Costar,

79 Corning Incorporated, Corning NY), in serum- and antibiotic-RPMI 1640 medium. Cells were

80 then treated with $20 \mathrm{ng} / \mathrm{mL}$ phorbol myristate acetate (PMA; Sigma-Aldrich) at $37^{\circ} \mathrm{C}$ in $5 \%$

$81 \mathrm{CO}_{2}$ for 12 hours, then washed and re-suspended in the same medium. After 48 hours of further

82 incubation, the cells were washed twice with serum- and antibiotic-free medium and used for 83 experiments.

84 The H292 human muco-epidermoid bronchiolar carcinoma cell line (ATCC) was used at the

85 passage numbers of 10-25. These cells were maintained in RPMI 1640 medium supplemented

86 with $10 \%$ heat inactivated FBS without antibiotics. Cells were grown at $37^{\circ} \mathrm{C}$ with $5 \% \mathrm{CO}_{2}$ and

87 seeded every 3-4 days when confluency approached $80 \%$. For viability testing, the cells were

88 detached using $0.5 \%$ Trypsin-EDTA (Gibco, Eugene, OR), centrifuged at $400 \times \mathrm{g}$ for 5 minutes,

89 washed with sterile PBS ( $\mathrm{pH}$ 7.4), and suspended in culture medium. Cell viability was

90 determined by the trypan blue exclusion method using a ViCell XR Cell Viability Analyzer

91 (Beckman Coulter, Brea, CA, USA).

92

93 Pseudomonas aeruginosa strains and in vitro infectious model 
94 Pseudomonas aeruginosa strain K wild type (PAK WT, provided by Dr. RJ Irvin, University of

95 Alberta, Edmonton, AB) and the isogenic P. aeruginosa mutant PAK fliC (flagella deficient,

96 provided by Dr. AS Prince, Columbia University, New York), as well as P. aeruginosa clinical

97 isolates from sputum samples of CF patients were used (Table). One clinical isolate from an

98 intermittently colonized and another from a chronically infected patient (the latter obtained during

99 longitudinal observation at the Danish CF Center) were kindly provided by Dr. N Høiby

100 (University Hospital Rigshospitalet, Copenhagen, Denmark). The characteristics of the isolates

101 are described in our previous study (Hawdon et al. 2010).

102 The bacteria were maintained on Luria Burtani (LB) medium (Fischer Scientific, Fair Lawn, NJ)

103 with $1 \%$ agar (LBA). A single colony of P. aeruginosa was grown overnight in sterile LB

104 medium on a shaking platform at $150 \mathrm{rpm}$ and diluted by a factor of 20 into fresh sterile LB

105 medium. Cultures were allowed to grow for approximately 1 hour, until mid-log phase when

106 optical density at $600 \mathrm{~nm}\left(\mathrm{OD}_{600}\right)$ reached 0.30 . The culture was then centrifuged at $3,500 \times g$ for

10720 minutes at $4^{\circ} \mathrm{C}$ and washed twice in PBS. Following the final re-suspension, bacteria were

108 diluted to an $\mathrm{OD}_{600}$ of 0.30 in RPMI 1640 that corresponded to approximately $2 \times 10^{8} \mathrm{CFU} / \mathrm{mL}$, as

109 determined by serial dilutions and drop plating on LBA. From this stock, bacteria were added to

110 either $\mathrm{H} 292$ cells to obtain a multiplicity of infection (MOI) of 50, as was optimized in our

111 previous experiments (Aval et al. 2013), or THP-1 cells at a MOI of 5. The latter conditions were

112 optimized using THP-1 cells infected with PAK during 1, 2, 6, 12, or 18 hours at MOI of 1, 5, or

11310.

114

115 Stimulation of THP-1 cells via Fcy-receptor cross-linking

116 The 96-well plates (Falcon, Corning Incorporated) were coated with human IgG (Sigma-Aldrich)

117 at concentrations of 10 and $100 \mu \mathrm{g} / \mathrm{mL}$ and incubated for 3 hours at $37^{\circ} \mathrm{C}$, followed by overnight

118 incubation at $4^{\circ} \mathrm{C}$, then the plates were washed twice with sterile PBS. THP- 1 cells at 
119 concentration of $0.4 \times 10^{6}$ cells $/ \mathrm{mL}$ in $200 \mu \mathrm{L}$ were added to the coated wells and incubated for 18 120 hours at $37^{\circ} \mathrm{C}$ with $5 \% \mathrm{CO}_{2}$.

121

122 Pretreatment with $\mathrm{R} 406$

123 THP-1 or H292 cells were grown for 24 hours to $0.4 \times 10^{6}$ cells $/ \mathrm{mL}$, or until they reached 124 approximately 80\% confluence, respectively, and R406 (AstraZeneca) dissolved in DMSO was

125 added to the medium to achieve a final concentration of $10 \mu \mathrm{M}$. The cells were incubated in the

126 presence of R406 for 1 hour, then washed once with PBS and used for experiments. These

127 conditions were developed based on published literature describing R406 pretreatments

128 (Braselmann et al. 2006; Spalton et al. 2009; Chen et al. 2008; Quiroga et al. 2009) and our

129 cellular viability testing using R406 concentrations of $1,5,10,15$, and $20 \mu \mathrm{M}$. No noticeable

130 effect of R406 concentrations up to $10 \mu \mathrm{M}$ on cell viability tested during one hour was detected

131 (97-99\% viable cells), nor significant decrease in either THP-1 or H292 cell viability following

132 18-hour-long incubation with $10 \mu \mathrm{M}$ of R406 occurred. Viability of THP-1 following 18 hour-

133 long incubation with R406 or without R406 was $82 \%$ and $75 \%$ (P>0.05), for $\mathrm{H} 292$ cells, it was

$13484 \%$ and $81 \%$, correspondingly $(\mathrm{P}>0.05)$.

135

136 Flow cytometry analysis of ICAM-1 expression

137 THP-1 cells $\left(0.4 \times 10^{6}\right)$ were infected with PAK WT for 6 hours at $37^{\circ} \mathrm{C}, 5 \% \mathrm{CO} 2$, then washed 138 and re-suspended in $100 \mu \mathrm{L}$ of $0.1 \%$ BSA-PBS containing PE-conjugated mAb against ICAM-1

139 (Mouse anti-human CD54, BD Pharmigen, Mississauga, ON) at a dilution of 1:50 and incubated

140 for 1 hour at $4^{\circ} \mathrm{C}$. Following incubation, cells were washed twice with PBS and analyzed by flow

141 cytometry on the FACSCailbur (BD Bioscience, Mississauga, ON, Canada). The data were

142 analyzed using CellQuest Pro software and expressed as mean fluorescence intensity (MFI).

144 ELISA for cytokine detection 
145 To measure the release of cytokines, PMA-differentiated THP-1 or H292 cells were infected with

146 P. aeruginosa (MOI of 10 , or 50 , correspondingly), for 1 hour at $37^{\circ} \mathrm{C}$, with $5 \% \mathrm{CO}_{2}$, and then

$147100 \mu \mathrm{g} / \mathrm{mL}$ gentamicin was added, followed by incubation for a further 17 hours at $37^{\circ} \mathrm{C}$ with $5 \%$

$148 \mathrm{CO} 2$. Following stimulation, cell culture supernatants were collected and stored at $-80^{\circ} \mathrm{C}$ until

149 analysis. The levels of TNF $\alpha$ and IL-1 $\beta$ were measured using eBioscience Ready-Set-Go ELISA

150 kits (San Diego, CA) according to the manufacturer's protocol. The lower detection limits of the

151 assays were $2 \mathrm{pg} / \mathrm{mL}$ for IL- $1 \beta$ and $4 \mathrm{pg} / \mathrm{mL}$ for TNF $\alpha$. Samples from three independent

152 experiments were run in triplicate.

153

154 Immunoprecipitation and Western blot

155 THP-1 cells $\left(2 \times 10^{6}\right)$ were infected with PAK WT at an MOI of 5 for 2 hours at $37^{\circ} \mathrm{C}, 5 \% \mathrm{CO}_{2}$.

156 Following stimulation, the cells were centrifuged, washed, re-suspended in $100 \mu \mathrm{L}$ of ice-cold

157 RIPA lysis buffer, and incubated for 30 minutes at $4{ }^{\circ} \mathrm{C}$. Following incubation, the cells were

158 centrifuged at $8,000 \times \mathrm{g}$ for 10 minutes and protein lysate was collected. Isolated proteins were

159 immunoprecipitated with polyclonal anti-Syk antibody (N-19) (Santa Cruz Biotehnology, CA)

160 using magnetic Protein A beads (Bio-Rad, Hercules CA), according to the manufacturer's

161 protocol. Samples were resolved by $12 \%$ SDS-PAGE and transferred to a nitrocellulose

162 membrane. Blots were blocked with 5\% nonfat dry milk in Tris-buffered saline containing $0.1 \%$

163 Tween 20, probed with primary antibody, i.e. anti-phospho-tyrosine (P-Tyr-100) (Cell Signaling

164 Technology), or monoclonal anti-syk antibodies (4D10) (Santa Cruz Biotechnology, CA)

165 followed by HRP-conjugated secondary antibody (7074S) (Cell Signaling Technology), and

166 developed using enhanced chemiluminescence. Bands were scanned and images analyzed using

167 ChemiDoc XRS (Bio-Rad). For analysis of total and phosphorylated intracellular signaling

168 proteins, THP-1 cells were stimulated with PAK (MOI of 5), for 15, 30, or 60 minutes at $37^{\circ} \mathrm{C}$.

169 Protein lysates were collected and stored at $-80^{\circ} \mathrm{C}$. For analysis of protein expression by Western

170 blot we used: monoclonal anti-JNK (D-2), anti-phospho JNK (G-7), anti-ERK 2 (12A4), anti- 


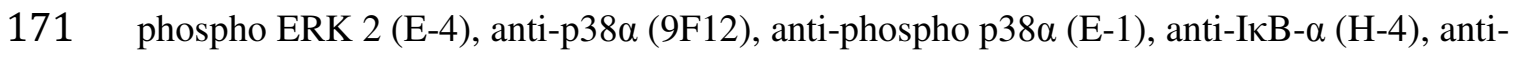

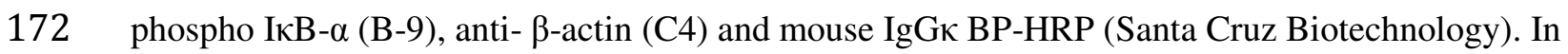

173 some cases, the blots were stripped and re-probed with other antibodies.

174

175 Statistical analysis

176 All the experiments were repeated at least 3 times. Data were expressed as mean $+/-$ SEM for $n$

177 independent experiments. For comparison of two sample means, Student's t test was applied.

178 GraphPad Prism 7.0 (La Jolla, CA, USA) was used for the analysis. P-values $<0.05$ were

179 considered significant. 


\section{Results:}

181 R406 down-regulates ICAM-1 expression induced by P. aeruginosa infection

183 As the intercellular adhesion molecule 1 (ICAM-1) typically becomes up-regulated during

184 inflammatory responses, particularly in cells infected with $P$. aeruginosa (Roebuck and Finnegan

185 1999; Sadikot et al. 2005) we tested the effect of R406 on the cell-surface expression of ICAM-1

186 in THP-1 cells exposed to a virulent P. aeruginosa strain K (PAK) at an MOI of 5. As shown on

187 Fig.1A, 6-hour long infection resulted in >15-fold increase in ICAM-1 mean fluorescence

188 intensity (MFI) compared to uninfected cells. One hour-long pre-incubation of THP-1 cells with

189 R406 used in concentrations between 0.1 and $20 \mu \mathrm{M}$ down-regulated ICAM-1 expression in a

190 dose-dependent manner, with a statistically significant effect for all the R406 concentrations $>0.5$

$191 \mu \mathrm{M}$ (Fig. 1A). There was no noticeable effect of R406 concentrations up to $10 \mu \mathrm{M}$ on cell

192 viability; the percentage of viable cells after one hour of incubation with R406 was 97-99\% (data

193 not shown). Likewise, one hour-long incubation of THP-1 cells with 1, 5, or $10 \mu \mathrm{M}$ of R406 did

194 not have any visible effect on the baseline ICAM-1 expression (data not shown).

196 To confirm the effect of R406 on Syk in our model, we stimulated THP-1 cells via Fc $\gamma$-receptor

197 (Fc $\gamma \mathrm{R})$ cross-linking, which is known to induce Syk-dependent signaling (Darby et al. 1994).

198 While stimulation of THP-1 cells with immobilized human IgG resulted in a significant increase

199 in ICAM-1 surface expression in a dose-dependent manner, pre-treatment with $10 \mu \mathrm{M}$ R406

200 caused an attenuation of ICAM-1 expression at both 10 and $100 \mu \mathrm{g} / \mathrm{mL} \mathrm{IgG} \mathrm{concentrations}$

201 (P<0.05) (Fig. 1B). Moreover, tyrosine phosphorylation of Syk induced by two hour-long

202 exposure of THP-1 cells to live bacteria was significantly down-regulated in cells, pre-treated

203 with $10 \mu \mathrm{M}$ R406 (Fig. 1C). 
205 These experiments imply that down-regulation of ICAM-1 in P. aeruginosa infected cells by 206 R406 could be mediated by inhibition of Syk-mediated signaling.

$208 R 406$ down-regulates the release of pro-inflammatory cytokines $T N F \alpha$ and IL-1 $\beta$ induced by $P$. 209 aeruginosa infection

211 To further test the effect of R406 in our model, we studied the release of cytokines TNF $\alpha$ and IL-

$2121 \beta$, which are the hallmarks of inflammatory responses caused by $P$. aeruginosa infection, by

213 using a virulent $P$. aeruginosa strain K (PAK WT), the isogenic $P$. aeruginosa mutant PAK fliC

214 (flagella-deficient), and clinical isolates from two CF patients (intermittently colonized and

215 chronically infected). One hour-long infection of differentiated THP-1 cells, or H292 cells with

216 PAK WT, followed by adding gentamicin with further 17 hours of incubation resulted in a large

217 TNF $\alpha$ release by both cell types, with THP-1 cells producing over 35-fold greater amount of this

218 cytokine as compared to H292 cells (Fig. 2B-C).

219 When flagella-deficient mutant (PAK fliC) was used for stimulation, TNF $\alpha$ release by both cell

220 lines was lower compared to stimulation with PAK WT $(\mathrm{P}<0.01)$ Interestingly, although

221 stimulation of THP-1 cells with either clinical $P$. aeruginosa isolate resulted in lower TNF $\alpha$

222 release $(\mathrm{P}<0.0001)$, in case of $\mathrm{H} 292$ cells, an isolate from a chronically infected CF patient

223 induced higher TNF $\alpha$ release compared to PAK WT $(\mathrm{P}<0.001)$, PAK fliC $(\mathrm{P}<0.0001)$, and isolate

224 from a CF patient with intermittent $P$. aeruginosa infection $(\mathrm{P}<0.001)$. Nevertheless, $\mathrm{TNF} \alpha$

225 release was significantly decreased in all infected cell cultures pretreated with R406, except for

226 THP-1 cells stimulated with an isolate from a chronically infected CF patient (Fig. 2B-C).

227 While unstimulated differentiated THP-1 cells only produced a low amount of IL-1 $\beta$ (78 \pm 9

$228 \mathrm{pg} / \mathrm{mL})$, infection with PAK WT resulted in a large increase in IL-1 $\beta$ release $(3993 \pm 245 \mathrm{pg} / \mathrm{mL}$,

$229 \mathrm{P}<0.0001)$. Stimulation with PAK fliC, or either isolate from a CF patient with intermittent or

230 chronically $P$. aeruginosa infected also significantly upregulated IL-1 $\beta$ release, although to a 
231 lesser degree compared to PAK WT $(\mathrm{P}<0.0001, \mathrm{P}<0.01$, and $\mathrm{P}<0.05$ respectively). The lowest 232 amount of IL-1 $\beta(1310 \pm 281 \mathrm{pg} / \mathrm{mL})$ was released by THP-1 cells stimulated with an isolate from 233 a chronically infected CF patient (significant lower than following stimulation with PAK WT, $234 \mathrm{P}<0.0001)$. Despite of different degrees of IL-1 $\beta$ release induced by $P$. aeruginosa strains, 235 pretreatment of differentiated THP-1 cells with R406 down-regulated this response (Fig. 2A). 236

237 R406 down-regulates the expression of phosphorylated ERK2, JNK, p-38, and IKB $\alpha$ in P. 238 aeruginosa infected THP-1 cells

240 As intracellular signaling molecules ERK2, JNK, p-38, and IאB $\alpha$ have been recognized as 241 important regulators of inflammatory responses induced by P. aeruginosa (Li et al. 1998; Ratner 242 et al. 2001; Esen et al. 2001), we investigated the effect of R406 on the expression of these total 243 and phosphorylated proteins in our model. Stimulation of THP-1 cells with PAK induced 244 significant up-regulation of phosphorylated ERK2 at $30 \mathrm{~min}(\mathrm{P}<0.01)$ and $60 \mathrm{~min}(\mathrm{P}<0.01)$, JNK 245 at $15 \min (\mathrm{P}<0.001), 30 \min (\mathrm{P}<0.001)$, and $60 \min (\mathrm{P}<0.001), \mathrm{p} 38$ at $15 \min (\mathrm{P}<0.001), 30 \min$ $246(\mathrm{P}<0.0001)$, and $60 \min (\mathrm{P}<0.0001)$, and $\mathrm{I} \kappa \mathrm{B} \alpha$ at $30 \min (\mathrm{P}<0.01)$ and $60 \min (\mathrm{P}<0.001)$.

247 Pretreatment of infected cells with R406 led to a decreased expression of all phosphorylated 248 signaling molecules that was statistically significant for JNK and p-38 at 15, 30, and 60 minutes 249 of stimulation, and for IKB $\alpha$ and ERK2 at 30 and 60 minutes of stimulation (Fig. 3A-D). 


\section{Discussion}

This study shows that a small molecule inhibitor of Syk down-regulates inflammatory responses of human cells infected with P. aeruginosa. Specifically, in monocytic cell line THP-1, R406 caused a significant decrease in cell surface expression of ICAM-1, an adhesion molecule, which mediates leukocyte migration to inflammatory sites, in a dose-dependent manner, as well as down-regulated the release of pro-inflammatory cytokines TNF $\alpha$ and IL-1 $\beta$. The transcriptional regulation of all these three molecules is largely dependent on the activation of transcription factor NF-kB, which is known to be a downstream target of Syk-mediated signaling along with the MAPK cascade (Costello et al. 1996; Darby et al. 1994). Indeed, R406 caused a decrease in the expression of phosphorylated ERK2, JNK and p-38, as well as of IкB $\alpha$; the latter, when phosphorylated, facilitates nuclear translocation of NF-kB, which is required for its activation and resulting production of inflammatory mediators (Akira and Kishimoto 1997). In our previous study, inhibition of Syk using small interfering RNA caused down-regulation of the MAPK cascade phosphorylation and nuclear translocation of p65 NF-kB induced by TNFa stimulation of lung epithelial cells (Ulanova et al. 2006). The data of the present study extend our earlier observations to monocytic cells and indicate that Syk is involved in the regulation of proinflammatory responses to $P$. aeruginosa infection via activation of downstream signalling pathways, including MAPK-mediated one. In support of this idea, we found an increase in the expression of tyrosine-phosphorylated Syk, an indicator of Syk activation, following two hourlong $P$. aeruginosa infection, and a decrease in the expression of phospho-Syk following pretreatment with R406 (Fig. 1C). As release of mature IL-1 $\beta$ requires inflammasome activation, in addition to IL-1 $\beta$ gene transcription, the effect of R406 on IL-1 $\beta$ release suggests Syk involvement in the regulation of inflammasome activation in our model (Dinarello 2009). This is not surprising as previous studies identified Syk as a key mediator of NLRP3 inflammasome activation and IL-1 $1 \beta$ secretion in innate immune cells stimulated with fungi and crystals (Gross et al. 2009; del Fresno et al. 2013; Mao et al. 2014; Lin et al. 2015; Lima-Junior et al. 2017). 
280 There are potentially multiple pathways of Syk activation during P. aeruginosa infection of 281 monocytic cells. This non-receptor protein tyrosine kinase is best known as a critical component 282 of immunoreceptor tyrosine-based activation motifs (ITAM)-dependent signaling in

283 hematopoietic cells involving Fc receptors, T-, B-, and NK cell receptors (Turner et al. 2000).

284 Congruently, in our experiments, we observed a strong inhibitory effect of R406 on ICAM-1

285 expression induced by a classical mechanism of Syk activation, i.e. via Fc $\gamma$ receptor cross-linking,

286 with ICAM-1 expression level decreased to the baseline while using a $10 \mu \mathrm{g} / \mathrm{mL}$ concentration of

287 human IgG for receptor activation (Fig. 1B). However, none of the cellular responses to $P$.

288 aeruginosa have been completely inhibited by R406, although we could achieve their significant

289 down-regulation using a concentration of $10 \mu \mathrm{M}$, which was commonly used in studies by others

290 (Braselmann et al. 2006); in case of ICAM-1, lower concentrations of 0.5 to $5 \mu \mathrm{M}$ were also

291 effective (Fig 1A). The data suggest that although Syk is certainly involved in the regulation of

292 inflammatory responses to $P$. aeruginosa infection, it does not represent the major pathway

293 among multiple mechanisms operating in cellular responses to this highly virulent

294 microorganism, which is capable to interact with many pathogen-recognition receptors, including

295 Toll-like receptors, Nod-like receptors, integrins, C-type lectins, asialoGM1, etc (Sadikot et al.

296 2005; DiMango et al. 1995; Skerrett et al. 2007). Ability of P. aeruginosa to stimulate TNF $\alpha$ and

297 IL-1 $\beta$ synthesis and release from human monocytes, and activation of transcription factors NF- $\kappa \mathrm{B}$

298 and AP in infected cells have been established by previous studies (Li et al. 1998; Kube et al.

299 2001; Lagoumintzis et al. 2003; Wehkamp et al. 2006). Syk involvement in the regulation of

300 signals generated by the engagement of TLR-4 complex by its ligand LPS in human neutrophils

301 and macrophages has also been previously demonstrated (Arndt et al. 2004; Ulanova et al. 2007;

302 Miller et al. 2012), and this mechanism likely operates in our model. Recent studies expanded our

303 understanding of the role of Syk in fine-tuning of cellular responses stimulated by the

304 engagement of innate immune receptors (Aouar et al. 2016; Yin et al. 2016). For example, it was 
305 demonstrated that in macrophages and dendritic cells, Syk regulates TNF $\alpha$ exocytosis induced by

306 stimulation of TLR9 by bacterial CpG DNA (Rao et al. 2013); such mechanism may potentially

307 be involved in responses of differentiated THP-1 cells to $P$. aeruginosa. In addition, innate

308 immune responses activated by P. aeruginosa result in the amplification of inflammatory

309 responses, as for example, $\mathrm{TNF} \alpha$ further activates the inflammatory cascade via its own receptor

310 associated signaling (Newton and Dixit 2012). The complexity of cellular responses to $P$.

311 aeruginosa is further augmented by cross talk among multiple signalling pathways, including

312 both pro- and anti-inflammatory (Lee and Kim 2007).

313

314 Syk may become activated following $P$. aeruginosa infection via several potential mechanisms. It

315 is well recognized that Syk is significantly involved in several ITAM-independent signalling

316 pathways, which are mediated by its interaction with G-protein coupled receptors, pattern

317 recognition, and cytokine receptors (Ulanova et al. 2005a; Mocsai et al. 2010). In particular, Syk

318 can be activated via interaction with integrin receptor cytoplasmic domains that is especially

319 significant in lung epithelial cells, which do not express the plethora of innate immune receptors

320 typical for leukocytes (Ulanova et al. 2005b). Our previous research demonstrated the

321 involvement of integrin receptors in P. aeruginosa internalization and recognition by A549

322 alveolar epithelial cells; moreover, the data suggested an important role of integrin-mediated

323 signaling in inflammation induced by this infection (Gravelle et al. 2010). In the present study,

324 the release of TNF $\alpha$ by infected bronchiolar epithelial cells was significantly down-regulated by

325 R406 implicating the involvement of Syk-dependent signaling in inflammatory responses to $P$.

326 aeruginosa by lung epithelial cells, in addition to monocytes (Fig 1C). Indeed, we have

327 previously demonstrated that H292 cells express Syk (Aval et al. 2013); however, it is uncertain

328 whether or not Syk is exclusively engaged via integrin receptors in this particular cell line, or

329 some other mechanisms, for example, those mediated by TNF-receptor signaling are involved

330 (Takada and Aggarwal 2004). 
332 Because Syk combines both kinase and adaptor protein properties, this molecule is capable to 333 interact with multiple protein targets, and this explains why its inhibition leads to numerous 334 biological effects. Indeed, Syk has been considered as a target for therapy of such diverse 335 conditions as allergic diseases, rheumatoid arthritis, systemic lupus erythematosus, idiopathic 336 thrombocytopenic purpura, and B-cell lymphoma, with several pharmacological compounds 337 undergoing clinical trials (Riccaboni et al. 2010). One potential application could be the use of

338 Syk inhibitors to dampen severe pro-inflammatory responses associated with pulmonary $P$.

339 aeruginosa infection, which affects CF patients, as well as occurs in ventilator-associated

340 pneumonia, aggravates the course of chronic obstructive pulmonary disease (COPD), and causes

341 severe complications in cancer patients with neutropenia, caused by chemotherapy that

342 predisposes to P. aeruginosa pneumonia (Saiman and Siegel 2004; Hakki et al. 2007; Crouch

343 Brewer et al. 1996; Lieberman and Lieberman 2003). In our previous study, we found that a

344 natural Syk inhibitor piceatannol significantly suppressed inflammation, oxidative stress,

345 apoptosis, and bacterial internalization in a model of $P$. aeruginosa infected pulmonary epithelial

346 cells, although not all of these outcomes could be attributed to Syk-specific effect (Aval et al.

347 2013). Results of the current study corroborate our previous observations using this time both a

348 model of infected THP-1 cells, which represent innate immune cells, and a bronchiolar epithelial

349 cell line H292 (Carney et al. 1985)

351 As bronchiolar epithelial cells represent the major component of the airway lining, have receptors

352 for P. aeruginosa, are the site of infection, generate inflammatory responses to this infectious

353 agent, and express Syk, they could be the major targets for potential therapeutic intervention

354 using Syk inhibitors. Importantly, the response of H292 cells to stimulation with various strains

355 of $P$. aeruginosa was noticeably different from the response by differentiated monocytic THP-1

356 cells (Fig. 2B-C). Although the release of TNF $\alpha$ by H292 cells infected with PAK WT or PAK 
357 fliC was approximately 50-times lower than the one by THP-1 cells, infection with clinical $P$.

358 aeruginosa isolates caused relatively higher TNF $\alpha$ production in $\mathrm{H} 292$ cells. In particular, H292

359 cells infected with $P$. aeruginosa of a CF patient with long-term chronic infection released the

360 largest amount of TNF $\alpha$ in comparison to other $P$. aeruginosa strains, i.e. $202 \pm 5 \mathrm{pg} / \mathrm{mL}$,

361 although THP-1 cells produced significantly less TNF $\alpha$ when stimulated with either clinical

362 isolate $(1545 \pm 237 \mathrm{pg} / \mathrm{mL}$ and $714 \pm 102 \mathrm{pg} / \mathrm{mL})$ as compared to both wild-type (4795 \pm 463

$363 \mathrm{pg} / \mathrm{mL})$ and flagella-deficient $(3691 \pm 255 \mathrm{pg} / \mathrm{mL})$ laboratory strains PAK. These data corroborate

364 our previous observations that $P$. aeruginosa isolates from chronically infected CF patients have

365 increased abilities of causing inflammatory responses of A549 alveolar epithelial cells in

366 comparison to bacteria from patients with intermittent $P$. aeruginosa colonization, owing to the

367 adaptation process in the CF long during long-term infectious process (Hawdon et al. 2010). The

368 isolate \#19731A/92 was obtained from a CF patient with 18-year long chronic P. aeruginosa

369 infection (Hawdon et al. 2010). As a flagella-deficient strain (PAK fliC) induced significantly

370 lower release of cytokines TNF $\alpha$ and IL-1 $\beta$ compared to the wild-type bacteria (Fig $2 \mathrm{~A}-\mathrm{C}$ ) these

371 data emphasize importance of flagella in stimulating potent pro-inflammatory responses to $P$.

372 aeruginosa infection via the activation of pattern-recognition receptors such as TLR5 and NLRC4

373 inflammasome (Blohmke et al. 2010; Zhao et al. 2011). Importantly, in bronchiolar epithelial

374 cells, R406 was able to significantly down-regulate TNF $\alpha$ release caused by $P$. aeruginosa

375 isolates from both chronically infected and intermittently colonized CF patients, although to a

376 lesser degree than when the inhibitor was applied to cells, stimulated with PAK WT or PAK fliC

377 (Fig 2C) suggesting potential clinical application of this inhibitor. However, as recent studies

378 found that Syk is essential for flagellin-specific T cell responses, it is important to consider

379 complexity of the regulatory role of this signaling molecule in immune responses (Atif et al.

380 2017).

381 
382 Compared to an early used inhibitor piceatannol, R406 has been demonstrated to be much more 383 selective for Syk. However, R406 is not entirely specific to Syk, and able to inhibit JAK2 in 384 addition to Syk of similar potency (Rolf et al. 2015). Although the present findings suggest Syk 385 involvement in the regulation of $P$. aeruginosa triggered inflammatory responses in both human 386 monocytic and bronchiolar epithelial cells, it will be highly desired to test more specific Syk

387 inhibitors. However, creating a truly selective Syk inhibitor apparently represents a challenge;

388 indeed, all of the existing compounds with Syk-inhibitory capacities, including the most recent

389 ones express certain off-target specificity (Ferguson et al. 2016; Yaron et al. 2016). When

390 Fostamatinib, of which R406 is the active metabolite, was tested in phase II-III clinical trials for

391 rheumatoid arthritis, adverse events related to its off-target effect have been noticed (Kunwar et

392 al. 2016). As it was demonstrated that inhibition of JAK2 down-regulated inflammatory

393 responses in an animal model of polymicrobial sepsis, certain off-target effects of R406 may

394 potentially be beneficial in case of $P$. aeruginosa infection (Pena et al. 2010). Conducting

395 clinical trials to ascertain capacity of this Syk inhibitor to alleviate exaggerated inflammatory

396 responses, which significantly contribute to the pathogenesis of $P$. aeruginosa pulmonary

397 infections may represent a sensible approach.

399 Acknowledgments

400 This work was supported by a National Science and Engineering Research Council Discovery

401 Grant and Ontario Lung Association Grant to M.U. We thank Dr. Niels Høiby (University

402 Hospital Rigshospitalet, Copenhagen, Denmark), Dr. Randal Irvin (University of Alberta,

403 Edmonton, Canada), and Dr. Alice Prince, Columbia University, New York) for kindly providing

$404 P$. aeruginosa clinical isolates and strains, AstraZeneka AB (Södertälje, Sweden) for providing

405 R406), and Jessica Rosengren (Lakehead University, Thunder Bay, Canada) for help with

406 optimizing experimental conditions.

407 


\section{References}

409 Akira, S. and Kishimoto, T. 1997. NF-IL6 and NF-kappa B in cytokine gene regulation. Adv $410 \quad$ Immunol, 65, 1-46.

411 Aouar, B., Kovarova, D., Letard, S., Font-Haro, A., Florentin, J., Weber, J., Durantel, D., 412 Chaperot, L., Plumas, J., Trejbalova, K., Hejnar, J., Nunes, J. A., Olive, D., Dubreuil, P., 413 Hirsch, I. and Stranska, R. 2016. Dual Role of the Tyrosine Kinase Syk in Regulation of 414 Toll-Like Receptor Signaling in Plasmacytoid Dendritic Cells. PLoS One, 11(6), e0156063. 415 doi: 10.1371/journal.pone.0156063. PMID: 27258042.

416 Arndt, P. G., Suzuki, N., Avdi, N. J., Malcolm, K. C. and Worthen, G. S. 2004. 417 Lipopolysaccharide-induced c-Jun NH2-terminal kinase activation in human neutrophils: 418 role of phosphatidylinositol 3-Kinase and Syk-mediated pathways. J Biol Chem, 279(12), 419 10883-91. doi: 10.1074/jbc.M309901200. PMID: 14699155.

420 Atif, S. M., Lee, S. J., Li, L. X., Uematsu, S., Akira, S., Gorjestani, S., Lin, X., Schweighoffer, E., 421 Tybulewicz, V. L. and McSorley, S. J. 2015. Rapid CD4+ T-cell responses to bacterial 422 flagellin require dendritic cell expression of Syk and CARD9. Eur J Immunol, 45(2), 513-

Aval, P. S., Werner, J., Cerqueira, A., Balfour-Boehm, J. and Ulanova, M. 2013. Piceatannol 425 modulates lung epithelial cellular responses to Pseudomonas aeruginosa. Inflamm Allergy Drug Targets, 12(5), 297-307.

Blohmke, C. J., Park, J., Hirschfeld, A. F., Victor, R. E., Schneiderman, J., Stefanowicz, D., Chilvers, M. A., Durie, P. R., Corey, M., Zielenski, J., Dorfman, R., Sandford, A. J., Daley, D. and Turvey, S. E. 2010. TLR5 as an anti-inflammatory target and modifier gene in cystic

431 Braselmann, S., Taylor, V., Zhao, H., Wang, S., Sylvain, C., Baluom, M., Qu, K., Herlaar, E., 432 Lau, A., Young, C., Wong, B. R., Lovell, S., Sun, T., Park, G., Argade, A., Jurcevic, S., 433 Pine, P., Singh, R., Grossbard, E. B., Payan, D. G. and Masuda, E. S. 2006. R406, an orally 
available spleen tyrosine kinase inhibitor blocks fc receptor signaling and reduces immune complex-mediated inflammation. J Pharmacol Exp Ther, 319(3), 998-1008. doi: 10.1124/jpet.106.109058. PMID: 16946104.

Carney, D. N., Gazdar, A. F., Bepler, G., Guccion, J. G., Marangos, P. J., Moody, T. W., Zweig, M. H. and Minna, J. D. 1985. Establishment and identification of small cell lung cancer cell lines having classic and variant features. Cancer Res, 45(6), 2913-23. 2985257.

Cha, H. S., Boyle, D. L., Inoue, T., Schoot, R., Tak, P. P., Pine, P. and Firestein, G. S. 2006. A novel spleen tyrosine kinase inhibitor blocks c-Jun N-terminal kinase-mediated gene expression in synoviocytes. J Pharmacol Exp Ther, 317(2), 571-8. doi: 10.1124/jpet.105.097436. PMID: 16452391.

Chen, L., Monti, S., Juszczynski, P., Daley, J., Chen, W., Witzig, T. E., Habermann, T. M., Kutok, J. L. and Shipp, M. A. 2008. SYK-dependent tonic B-cell receptor signaling is a rational treatment target in diffuse large B-cell lymphoma. Blood, 111(4), 2230-7. doi: 10.1182/blood-2007-07-100115. PMID: 18006696.

Cheng, K., Ashby, D. and Smyth, R. L. 2013. Oral steroids for long-term use in cystic fibrosis. Cochrane Database Syst Rev(6), CD000407. doi: 10.1002/14651858.CD000407.pub3. PMID: 23794322.

Costello, P. S., Turner, M., Walters, A. E., Cunningham, C. N., Bauer, P. H., Downward, J. and Tybulewicz, V. L. 1996. Critical role for the tyrosine kinase Syk in signalling through the high affinity IgE receptor of mast cells. Oncogene, 13(12), 2595-605.

Crouch Brewer, S., Wunderink, R. G., Jones, C. B. and Leeper, K. V., Jr. 1996. Ventilatorassociated pneumonia due to Pseudomonas aeruginosa. Chest, 109(4), 1019-29.

Darby, C., Geahlen, R. L. and Schreiber, A. D. 1994. Stimulation of macrophage Fc gamma RIIIA activates the receptor-associated protein tyrosine kinase Syk and induces phosphorylation of multiple proteins including p95Vav and p62/GAP-associated protein. J Immunol, 152(11), 5429-37. 
460 del Fresno, C., Soulat, D., Roth, S., Blazek, K., Udalova, I., Sancho, D., Ruland, J. and Ardavin,

461 C. 2013. Interferon-beta production via Dectin-1-Syk-IRF5 signaling in dendritic cells is

462 crucial for immunity to C. albicans. Immunity, 38(6), 1176-86. doi:

463 10.1016/j.immuni.2013.05.010. PMID: 23770228.

464 DiMango, E., Zar, H. J., Bryan, R. and Prince, A. 1995. Diverse Pseudomonas aeruginosa gene

465 products stimulate respiratory epithelial cells to produce interleukin-8. J Clin Invest, 96(5),

466 2204-10. doi: 10.1172/JCI118275. PMID: 7593606.

467 Dinarello, C. A. 2009. Immunological and inflammatory functions of the interleukin-1 family.

468 Annu Rev Immunol, 27, 519-50. doi: 10.1146/annurev.immunol.021908.132612. PMID:

$469 \quad 19302047$.

470 Esen, M., Grassme, H., Riethmuller, J., Riehle, A., Fassbender, K. and Gulbins, E. 2001. Invasion

471 of human epithelial cells by Pseudomonas aeruginosa involves src-like tyrosine kinases

472 p60Src and p59Fyn. Infect Immun, 69(1), 281-7. doi: 10.1128/IAI.69.1.281-287.2001.

$473 \quad$ PMID: 11119516.

474 Feldman, M., Bryan, R., Rajan, S., Scheffler, L., Brunnert, S., Tang, H. and Prince, A. 1998. Role

475 of flagella in pathogenesis of Pseudomonas aeruginosa pulmonary infection. Infect Immun,

$476 \quad 66(1), 43-51.9423837$

477 Ferguson, G. D., Delgado, M., Plantevin-Krenitsky, V., Jensen-Pergakes, K., Bates, R. J., Torres,

478 S., Celeridad, M., Brown, H., Burnett, K., Nadolny, L., Tehrani, L., Packard, G., Pagarigan,

479 B., Haelewyn, J., Nguyen, T., Xu, L., Tang, Y., Hickman, M., Baculi, F., Pierce, S.,

480 Miyazawa, K., Jackson, P., Chamberlain, P., LeBrun, L., Xie, W., Bennett, B. and Blease, K.

481 2016. A Novel Triazolopyridine-Based Spleen Tyrosine Kinase Inhibitor That Arrests Joint

482 Inflammation. PLoS One, 11(1), e0145705. doi: 10.1371/journal.pone.0145705. PMID:

48326756335.

484 Gravelle, S., Barnes, R., Hawdon, N., Shewchuk, L., Eibl, J., Lam, J. S. and Ulanova, M. 2010.

485 Up-regulation of integrin expression in lung adenocarcinoma cells caused by bacterial 
infection: in vitro study. Innate Immun, 16(1), 14-26. doi: 10.1177/1753425909106170. PMID: 19710103.

488 Gross, O., Poeck, H., Bscheider, M., Dostert, C., Hannesschlager, N., Endres, S., Hartmann, G., 489 Tardivel, A., Schweighoffer, E., Tybulewicz, V., Mocsai, A., Tschopp, J. and Ruland, J. 490 2009. Syk kinase signalling couples to the Nlrp3 inflammasome for anti-fungal host defence. 491 Nature, 459(7245), 433-6. doi: 10.1038/nature07965. PMID: 19339971.

492 Hakki, M., Limaye, A. P., Kim, H. W., Kirby, K. A., Corey, L. and Boeckh, M. 2007. Invasive 493 Pseudomonas aeruginosa infections: high rate of recurrence and mortality after 494 hematopoietic cell transplantation. Bone Marrow Transplant, 39(11), 687-93. doi: $495 \quad$ 10.1038/sj.bmt.1705653. PMID: 17401395.

496 Hawdon, N. A., Aval, P. S., Barnes, R. J., Gravelle, S. K., Rosengren, J., Khan, S., Ciofu, O., 497 Johansen, H. K., Hoiby, N. and Ulanova, M. 2010. Cellular responses of A549 alveolar 498 epithelial cells to serially collected Pseudomonas aeruginosa from cystic fibrosis patients at different stages of pulmonary infection. FEMS Immunol Med Microbiol, 59(2), 207-20. doi: 10.1111/j.1574-695X.2010.00693.x. PMID: 20528926. aeruginosa pathogenesis. Med Mal Infect, 36(2), 78-91. doi: 10.1016/j.medmal.2005.10.007. PMID: 16427231.

Kube, D., Sontich, U., Fletcher, D. and Davis, P. B. 2001. Proinflammatory cytokine responses to Physiol, 280(3), L493-502.

Kunwar, S., Devkota, A. R. and Ghimire, D. K. 2016. Fostamatinib, an oral spleen tyrosine kinase inhibitor, in the treatment of rheumatoid arthritis: a meta-analysis of randomized controlled trials. Rheumatol Int, 36(8), 1077-87. doi: 10.1007/s00296-016-3482-7. PMID: 27113955.

Lagoumintzis, G., Christofidou, M., Dimitracopoulos, G. and Paliogianni, F. 2003. Pseudomonas 
512 aeruginosa slime glycolipoprotein is a potent stimulant of tumor necrosis factor alpha gene

513 expression and activation of transcription activators nuclear factor kappa B and activator

514 protein 1 in human monocytes. Infect Immun, 71(8), 4614-22.

515 Lee, M. S. and Kim, Y. J. 2007. Signaling pathways downstream of pattern-recognition receptors

516 and their cross talk. Annu Rev Biochem, 76, 447-80. doi:

$517 \quad$ 10.1146/annurev.biochem.76.060605.122847. PMID: 17328678.

518 Li, J. D., Feng, W., Gallup, M., Kim, J. H., Gum, J., Kim, Y. and Basbaum, C. 1998. Activation

519 of NF-kappaB via a Src-dependent Ras-MAPK-pp90rsk pathway is required for

520 Pseudomonas aeruginosa-induced mucin overproduction in epithelial cells. Proc Natl Acad

$521 \quad$ Sci U S A, 95(10), 5718-23.

522 Lieberman, D. and Lieberman, D. 2003. Pseudomonal infections in patients with COPD:

523 epidemiology and management. Am J Respir Med, 2(6), 459-68.

524 Lima-Junior, D. S., Mineo, T. W. P., Calich, V. L. G. and Zamboni, D. S. 2017. Dectin-1

525 Activation during Leishmania amazonensis Phagocytosis Prompts Syk-Dependent Reactive

526 Oxygen Species Production To Trigger Inflammasome Assembly and Restriction of Parasite

527 Replication. J Immunol, 199(6), 2055-2068. doi: 10.4049/jimmunol.1700258. PMID:

52828784846.

529 Lin, Y. C., Huang, D. Y., Wang, J. S., Lin, Y. L., Hsieh, S. L., Huang, K. C. and Lin, W. W.

530 2015. Syk is involved in NLRP3 inflammasome-mediated caspase-1 activation through

531 adaptor ASC phosphorylation and enhanced oligomerization. J Leukoc Biol, 97(5), 825-835.

532 doi: 10.1189/jlb.3HI0814-371RR. PMID: 25605870.

533 Mao, L., Zhang, L., Li, H., Chen, W., Wang, H., Wu, S., Guo, C., Lu, A., Yang, G., An, L., Abliz,

534 P. and Meng, G. 2014. Pathogenic fungus Microsporum canis activates the NLRP3

535 inflammasome. Infect Immun, 82(2), 882-92. doi: 10.1128/IAI.01097-13. PMID: 24478101.

536 McAdoo, S. P. and Tam, F. W. 2011. Fostamatinib Disodium. Drugs Future, 36(4), 273.

537 Miller, Y. I., Choi, S. H., Wiesner, P. and Bae, Y. S. 2012. The SYK side of TLR4: signalling 

mechanisms in response to LPS and minimally oxidized LDL. Br J Pharmacol, 167(5), 9909. doi: 10.1111/j.1476-5381.2012.02097.x. PMID: 22776094.

540 Mocsai, A., Ruland, J. and Tybulewicz, V. L. 2010. The SYK tyrosine kinase: a crucial player in 541 diverse biological functions. Nat Rev Immunol, 10(6), 387-402. doi: 10.1038/nri2765. $542 \quad$ PMID: 20467426.

543 Newton, K. and Dixit, V. M. 2012. Signaling in innate immunity and inflammation. Cold Spring $544 \quad$ Harb Perspect Biol, 4(3). doi: 10.1101/cshperspect.a006049. PMID: 22296764.

545 Pasloske, B. L., Finlay, B. B. and Paranchych, W. 1985. Cloning and sequencing of the

546 Pseudomonas aeruginosa PAK pilin gene. FEBS Lett, 183(2), 408-12. 2985436.

547 Pena, G., Cai, B., Deitch, E. A. and Ulloa, L. 2010. JAK2 inhibition prevents innate immune 548 responses and rescues animals from sepsis. J Mol Med (Berl), 88(8), 851-9. doi: 549 10.1007/s00109-010-0628-z. PMID: 20393690.

550 Quiroga, M. P., Balakrishnan, K., Kurtova, A. V., Sivina, M., Keating, M. J., Wierda, W. G., 551 Gandhi, V. and Burger, J. A. 2009. B-cell antigen receptor signaling enhances chronic 552 lymphocytic leukemia cell migration and survival: specific targeting with a novel spleen 553 tyrosine kinase inhibitor, R406. Blood, 114(5), 1029-37. doi: 10.1182/blood-2009-03212837. PMID: 19491390.

Rao, S., Liu, X., Freedman, B. D. and Behrens, E. M. 2013. Spleen tyrosine kinase (Syk)dependent calcium signals mediate efficient CpG-induced exocytosis of tumor necrosis

Ratner, A. J., Bryan, R., Weber, A., Nguyen, S., Barnes, D., Pitt, A., Gelber, S., Cheung, A. and 560 Prince, A. 2001. Cystic fibrosis pathogens activate Ca2+-dependent mitogen-activated 561 protein kinase signaling pathways in airway epithelial cells. J Biol Chem, 276(22), 19267562 75. doi: 10.1074/jbc.M007703200. PMID: 11278360.

563 Riccaboni, M., Bianchi, I. and Petrillo, P. 2010. Spleen tyrosine kinases: biology, therapeutic 
564 targets and drugs. Drug Discov Today, 15(13-14), 517-30. doi: $565 \quad$ 10.1016/j.drudis.2010.05.001. PMID: 20553955.

566 Roebuck, K. A. and Finnegan, A. 1999. Regulation of intercellular adhesion molecule-1 (CD54) 567 gene expression. J Leukoc Biol, 66(6), 876-88.

568 Rolf, M. G., Curwen, J. O., Veldman-Jones, M., Eberlein, C., Wang, J., Harmer, A., Hellawell, C.

569 J. and Braddock, M. 2015. In vitro pharmacological profiling of R406 identifies molecular 570 targets underlying the clinical effects of fostamatinib. Pharmacol Res Perspect, 3(5), e00175. 571 doi: 10.1002/prp2.175. PMID: 26516587.

572 Sadikot, R. T., Blackwell, T. S., Christman, J. W. and Prince, A. S. 2005. Pathogen-host 573 interactions in Pseudomonas aeruginosa pneumonia. Am J Respir Crit Care Med, 171(11), 574 1209-23. doi: 10.1164/rccm.200408-1044SO. PMID: 15695491.

575 Saiman, L. and Siegel, J. 2004. Infection control in cystic fibrosis. Clin Microbiol Rev, 17(1), 57$576 \quad 71$.

577 Skerrett, S. J., Wilson, C. B., Liggitt, H. D. and Hajjar, A. M. 2007. Redundant Toll-like receptor 578 signaling in the pulmonary host response to Pseudomonas aeruginosa. Am J Physiol Lung 579 Cell Mol Physiol, 292(1), L312-22. doi: 10.1152/ajplung.00250.2006. PMID: 16936244.

580 Spalton, J. C., Mori, J., Pollitt, A. Y., Hughes, C. E., Eble, J. A. and Watson, S. P. 2009. The 581 novel Syk inhibitor R406 reveals mechanistic differences in the initiation of GPVI and 582 CLEC-2 signaling in platelets. J Thromb Haemost, 7(7), 1192-9. doi: 10.1111/j.1538$583 \quad$ 7836.2009.03451.x. PMID: 19422460.

584 Takada, Y. and Aggarwal, B. B. 2004. TNF activates Syk protein tyrosine kinase leading to TNF585 induced MAPK activation, NF-kappaB activation, and apoptosis. J Immunol, 173(2), 1066$586 \quad 77.15240695$.

587 Turner, M., Schweighoffer, E., Colucci, F., Di Santo, J. P. and Tybulewicz, V. L. 2000. Tyrosine 588 kinase SYK: essential functions for immunoreceptor signalling. Immunol Today, 21(3), 14858954. 
590 Ulanova, M., Asfaha, S., Stenton, G., Lint, A., Gilbertson, D., Schreiber, A. and Befus, D. 2007. 591 Involvement of Syk protein tyrosine kinase in LPS-induced responses in macrophages. J 592 Endotoxin Res, 13(2), 117-25. doi: 10.1177/0968051907079125. PMID: 17621553.

593 Ulanova, M., Duta, F., Puttagunta, L., Schreiber, A. D. and Befus, A. D. 2005a. Spleen tyrosine 594 kinase (Syk) as a novel target for allergic asthma and rhinitis. Expert Opin Ther Targets, 595 9(5), 901-21. doi: 10.1517/14728222.9.5.901. PMID: 16185147.

596 Ulanova, M., Marcet-Palacios, M., Munoz, S., Asfaha, S., Kim, M. K., Schreiber, A. D. and 597 Befus, A. D. 2006. Involvement of Syk kinase in TNF-induced nitric oxide production by 598 airway epithelial cells. Biochem Biophys Res Commun, 351(2), 431-7. doi: $599 \quad$ 10.1016/j.bbrc.2006.10.073. PMID: 17070777.

600 Ulanova, M., Puttagunta, L., Marcet-Palacios, M., Duszyk, M., Steinhoff, U., Duta, F., Kim, M. 601 K., Indik, Z. K., Schreiber, A. D. and Befus, A. D. 2005b. Syk tyrosine kinase participates in 602 beta1-integrin signaling and inflammatory responses in airway epithelial cells. Am J Physiol 603 604

605 Wehkamp, K., Schwichtenberg, L., Schroder, J. M. and Harder, J. 2006. Pseudomonas 606 aeruginosa- and IL-1beta-mediated induction of human beta-defensin- 2 in keratinocytes is 607 controlled by NF-kappaB and AP-1. J Invest Dermatol, 126(1), 121-7. doi: 608 609 Yaron, J. R., Rao, M. Y., Gangaraju, S., Zhang, L., Kong, X., Su, F., Tian, Y., Glenn, H. L. and 610 Meldrum, D. R. 2016. The oxindole Syk inhibitor OXSI-2 blocks nigericin-induced 611 inflammasome signaling and pyroptosis independent of potassium efflux. Biochem Biophys 612 Res Commun, 472(3), 545-50. doi: 10.1016/j.bbrc.2016.03.021. PMID: 26970308.

613 Yin, H., Zhou, H., Kang, Y., Zhang, X., Duan, X., Alnabhan, R., Liang, S., Scott, D. A., Lamont, 614 R. J., Shang, J. and Wang, H. 2016. Syk negatively regulates TLR4-mediated IFNbeta and 615 IL-10 production and promotes inflammatory responses in dendritic cells. Biochim Biophys 
616 Acta, 1860(3), 588-98. doi: 10.1016/j.bbagen.2015.12.012.PubMed PMID: 26708990.

617 Zhao, Y., Yang, J., Shi, J., Gong, Y. N., Lu, Q., Xu, H., Liu, L. and Shao, F. 2011. The NLRC4

618 inflammasome receptors for bacterial flagellin and type III secretion apparatus. Nature,

619 477(7366), 596-600. doi: 10.1038/nature10510. PMID: 21918512.

620 


\section{$621 \quad$ Figure Legends}

622

623 Fig. 1 The effect of R406 on ICAM-1 expression induced by Pseudomonas aeruginosa strain K 624 (PAK WT) infection, or Fc $\gamma$ receptor (Fc $\gamma \mathrm{R})$ cross-linking. a) One hour-long pre-treatment of 625 THP-1 cells with various concentrations of R406 decreased ICAM-1 expression in THP-1 cells 626 infected with PAK at an MOI of 5 for 6 hours in a dose-dependent manner. b) Pre-treatment of

627 THP-1 cells with $10 \mu \mathrm{M}$ R406 for 1 hour prior to their stimulation with immobilized human $\operatorname{IgG}$

628 at concentrations of 10 and $100 \mu \mathrm{g} / \mathrm{mL}$ decreased up-regulation of ICAM-1. THP-1 cells were

629 infected with PAK or stimulated via Fc $\gamma \mathrm{R}$ cross-linking as described in Materials \& Methods, and

630 ICAM-1 surface expression determined using immunostaining and flow cytometry analysis. Data

631 are expressed as mean fluorescence intensity (MFI). Results represent the mean \pm SEM of 3

632 independent experiments; \#\#\#P<0.001, difference between un-stimulated and stimulated cells; *P

$633<0.05, * * \mathrm{P}<0.01, * * * \mathrm{P}<0.001$, difference between stimulated R406 treated vs. un-treated cells. c)

634 Ratios of Western blotting band intensity of Syk phosphorylated on tyrosine to total Syk. The

635 lanes from left to right: un-stimulated THP-1 cells, THP-1 cells infected with PAK for 2 hours,

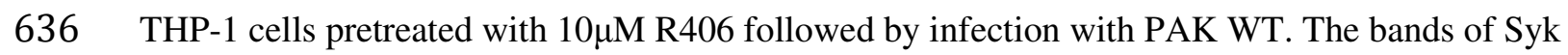

637 and phosphotyrosine on immunoprecipitated Syk were detected at $72 \mathrm{kDa}$. Results represent 3

638 independent experiments. *** $\mathrm{P}<0.001$, difference between $\mathrm{R} 406$-treated and un-treated infected 639 THP-1 cells.

640

641 Fig. 2 The effect of R406 pre-treatment on cytokine expression induced by Pseudomonas

642 aeruginosa.

643 Differentiated THP-1 cells were infected with $P$. aeruginosa for 1 hours at an MOI of 10 per $1 \times$

$64410^{6}$ cells, and cultured for another $17 \mathrm{~h}$ in the presence of $100 \mu \mathrm{g} / \mathrm{mL}$ gentamicin. Unstimulated

645 differentiated THP-1 cells $\left(1 \times 10^{6}\right)$ in complete culture medium served as a negative control. The

646 supernatant was collected and IL-1 $\beta(\mathbf{A})$ and TNF $\alpha(\mathbf{B})$ concentrations $(\mathrm{pg} / \mathrm{mL})$ in culture 
647 supernatants were examined using ELISA. For TNF $\alpha$ expression by H292 cells (C), the cells 648 were infected at an MOI of 50 for $1 \mathrm{~h}$ and further cultured as described above. In samples

649 involving R406, cells were pre-treated with $10 \mu \mathrm{M}$ R406 for 1 hour prior to infection. Results 650 represent the mean $\pm \mathrm{SEM}$ of 3 independent experiments; $* \mathrm{P}<0.05$, ** $\mathrm{P}<0.01, * * * \mathrm{P}<0.001$, $651 * * * * \mathrm{P}<0.0001$, difference between $\mathrm{R} 406-$ treated and un-treated infected cells.

652

653 Fig. 3 The effect of R406 on expression of phosphorylated and total intracellular signaling 654 proteins.

655 THP-1 cells were stimulated with P. aeruginosa strain K (PAK WT) at an MOI of 5 for 15, 30, or 65660 minutes. Following stimulation, the levels of total and phosphorylated ERK2 (42 kDa), JNK 657 (46 kDa), IкB $\alpha(41 \mathrm{kDa})$, and p-38 (38 kDa) were determined in cellular lysates by Western blot.

658 Results are expressed as ratios of phosphorylated/total protein band intensity. In samples

659 involving R406, cells were pre-treated with $10 \mu \mathrm{M}$ R406 for 1 hour prior to infection. $\beta$-actin

660 served as a loading control. Results represent the mean \pm SEM of 2 independent experiments; * $\mathrm{P}$

$661<0.05, * * \mathrm{P}<0.01, * * * \mathrm{P}<0.001, * * * * \mathrm{P}<0.0001$, difference between $\mathrm{R} 406$-treated and un-

662 treated infected cells.

663 
1 Table 1: Strains and Clinical Isolates of $P$. aeruginosa used in this study.

2

\begin{tabular}{ll}
\hline Strain/Isolate & Source/Reference \\
\hline Wild-type PAK (PAK WT) & R.J. Irvin/Pasloske et al. (1985) \\
\hline Flagella-deficient PAK (PAK fliC) & A.S. Prince/Feldman et al. (1998) \\
\hline Isolate from intermittently colonized CF & Danish CF Centre/Hawdon et al. (2010) \\
patient (9793/92) &
\end{tabular}

Isolate from chronically infected $\mathrm{CF}$

patient (19731A/92)

Danish CF Centre/Hawdon et al. (2010)

3 
A

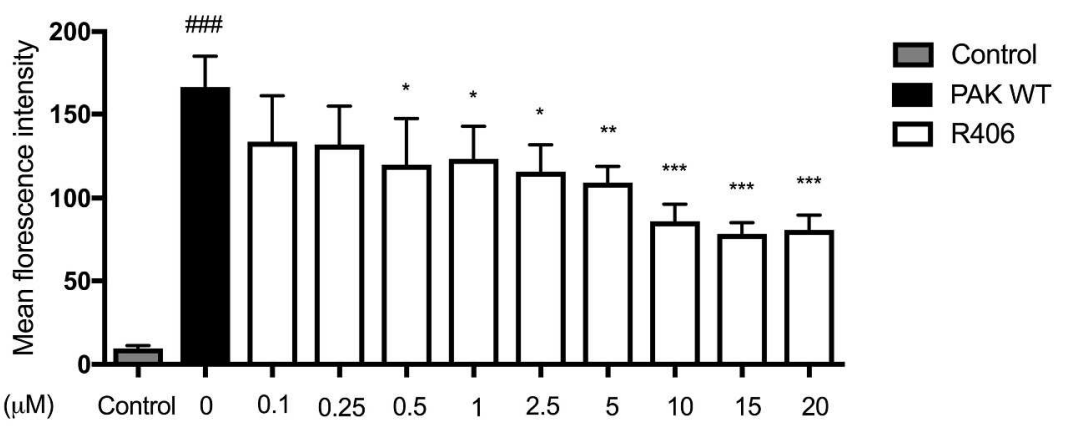

B
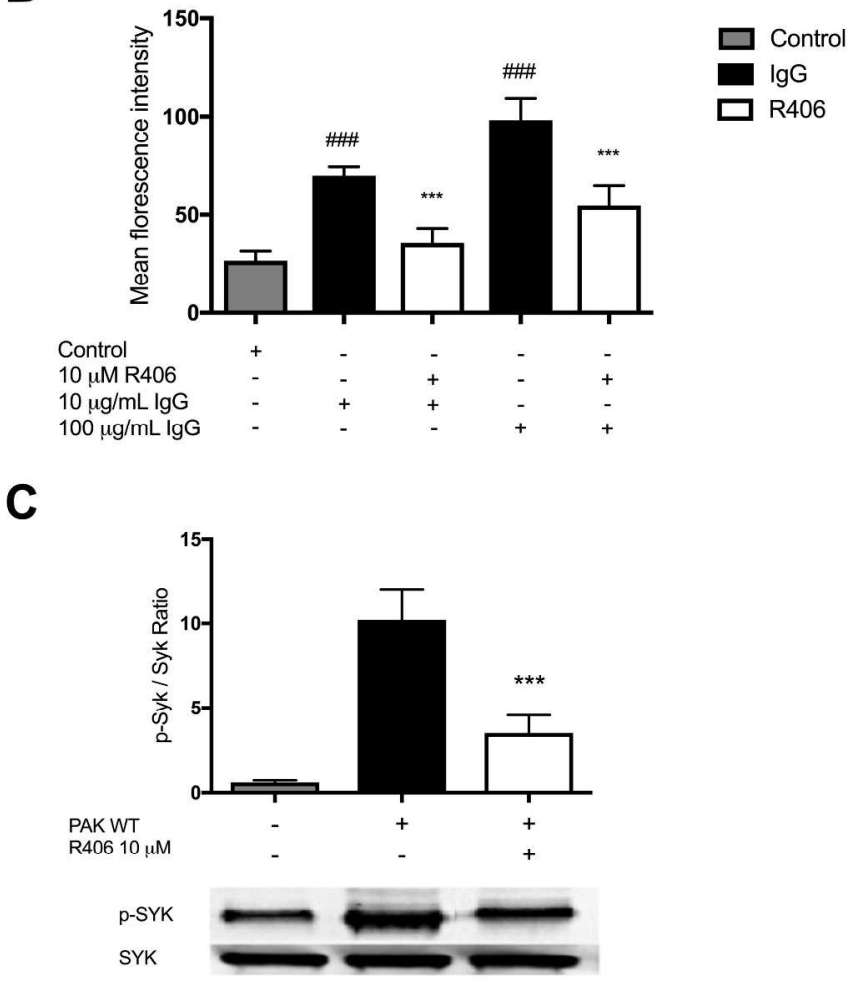

Fig. 1 The effect of R406 on ICAM-1 expression induced by Pseudomonas aeruginosa strain K (PAK WT) infection, or Fcy receptor (FCYR) cross-linking. a) One hour-long pre-treatment of THP-1 cells with various concentrations of R406 decreased ICAM-1 expression in THP-1 cells infected with PAK at an MOI of 5 for 6

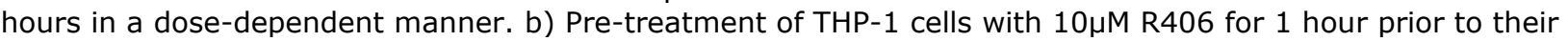
stimulation with immobilized human IgG at concentrations of 10 and $100 \mu \mathrm{g} / \mathrm{mL}$ decreased up-regulation of ICAM-1. THP-1 cells were infected with PAK or stimulated via FcyR cross-linking as described in Materials \& Methods, and ICAM-1 surface expression determined using immunostaining and flow cytometry analysis.

Data are expressed as mean fluorescence intensity (MFI). Results represent the mean \pm SEM of 3 independent experiments; \#\#\# $\mathrm{P}<0.001$, difference between un-stimulated and stimulated cells; $* \mathrm{P}<0.05$, $* * P<0.01, * * * P<0.001$, difference between stimulated R406 treated vs. un-treated cells. c) Ratios of Western blotting band intensity of Syk phosphorylated on tyrosine to total Syk. The lanes from left to right: un-stimulated THP-1 cells, THP-1 cells infected with PAK for 2 hours, THP- 1 cells pretreated with $10 \mu \mathrm{M}$ R406 followed by infection with PAK WT. The bands of Syk and phosphotyrosine on immunoprecipitated Syk were 
detected at 72 kDa. Results represent 3 independent experiments. $* * * \mathrm{P}<0.001$, difference between R406treated and un-treated infected THP-1 cells.

$232 \times 305 \mathrm{~mm}(300 \times 300 \mathrm{DPI})$ 

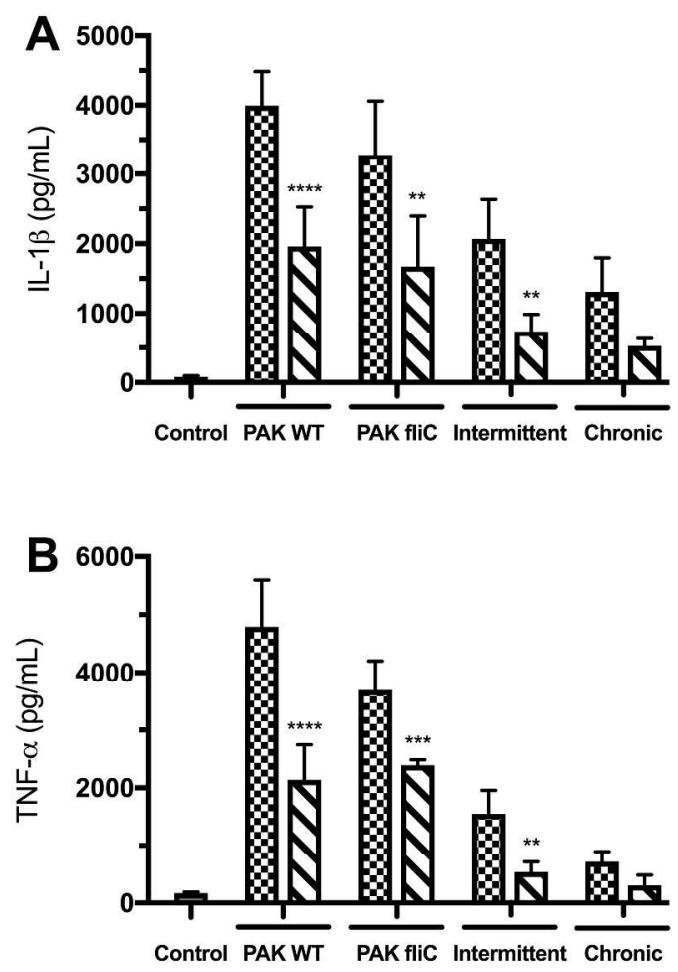

Do. No pre-treatment

R406 pre-treatment

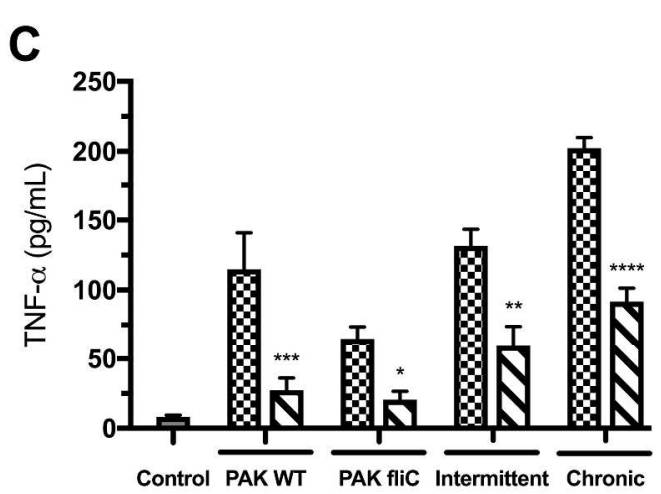

No pre-treatment

DV R406 pre-treatment

Fig. 2 The effect of R406 pre-treatment on cytokine expression induced by Pseudomonas aeruginosa.\%"Differentiated THP-1 cells were infected with P. aeruginosa for 1 hours at an MOI of 10 per 1 $\times 106$ cells, and cultured for another $17 \mathrm{~h}$ in the presence of $100 \mu \mathrm{g} / \mathrm{mL}$ gentamicin. Unstimulated differentiated THP-1 cells $(1 \times 106)$ in complete culture medium served as a negative control. The supernatant was collected and IL-1 $\beta(A)$ and TNFa (B) concentrations $(\mathrm{pg} / \mathrm{mL})$ in culture supernatants were examined using ELISA. For TNFa expression by $\mathrm{H} 292$ cells (C), the cells were infected at an MOI of 50 for 1 $\mathrm{h}$ and further cultured as described above. In samples involving R406, cells were pre-treated with $10 \mu \mathrm{M}$ R406 for 1 hour prior to infection. Results represent the mean \pm SEM of 3 independent experiments; $* \mathrm{P}<$ $0.05, * * \mathrm{P}<0.01, * * * \mathrm{P}<0.001, * * * * \mathrm{P}<0.0001$, difference between R406-treated and un-treated infected cells. 
A

ERK2
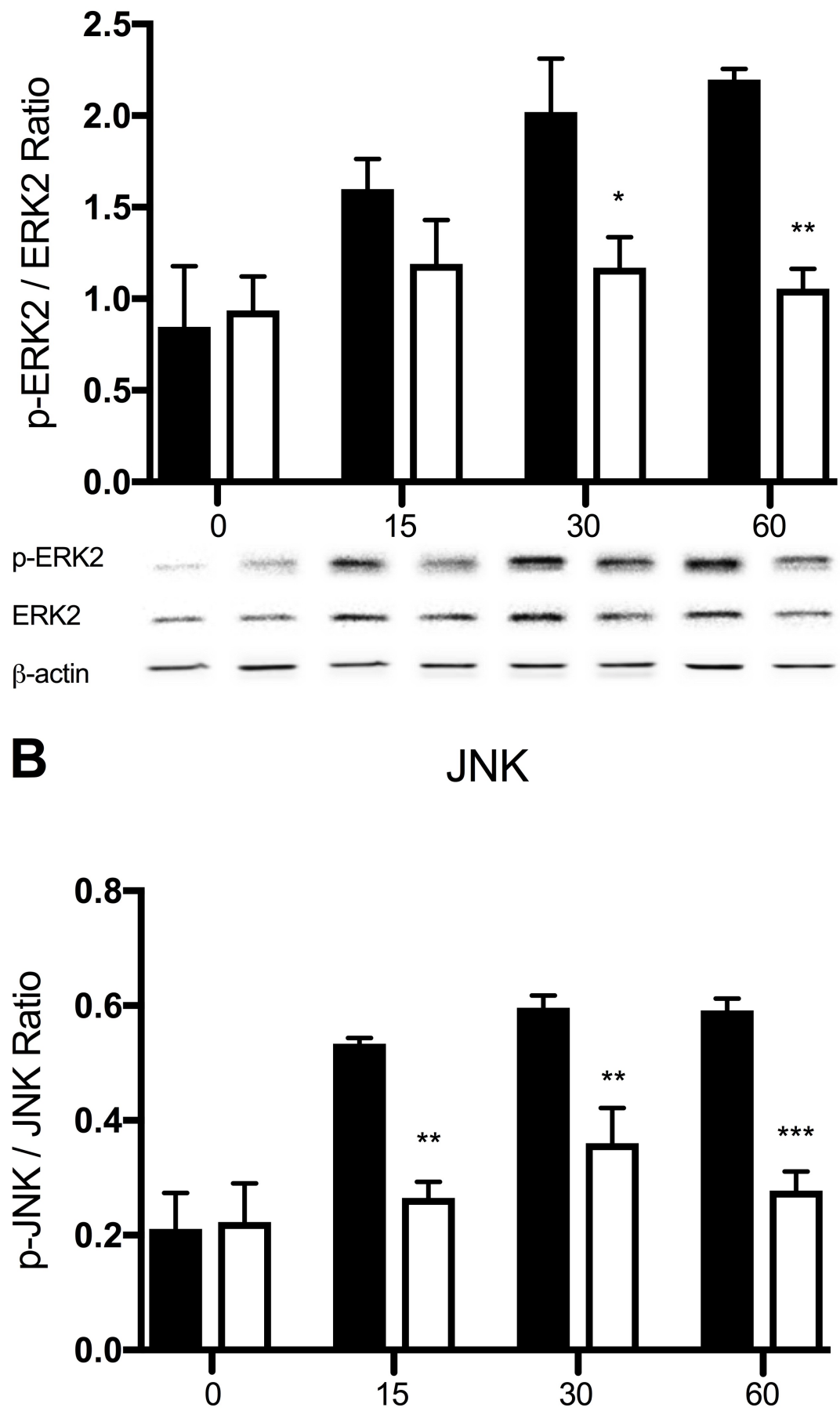

p-JNK

JNK

$\beta$-actin 
C

$\mid \kappa B \alpha$

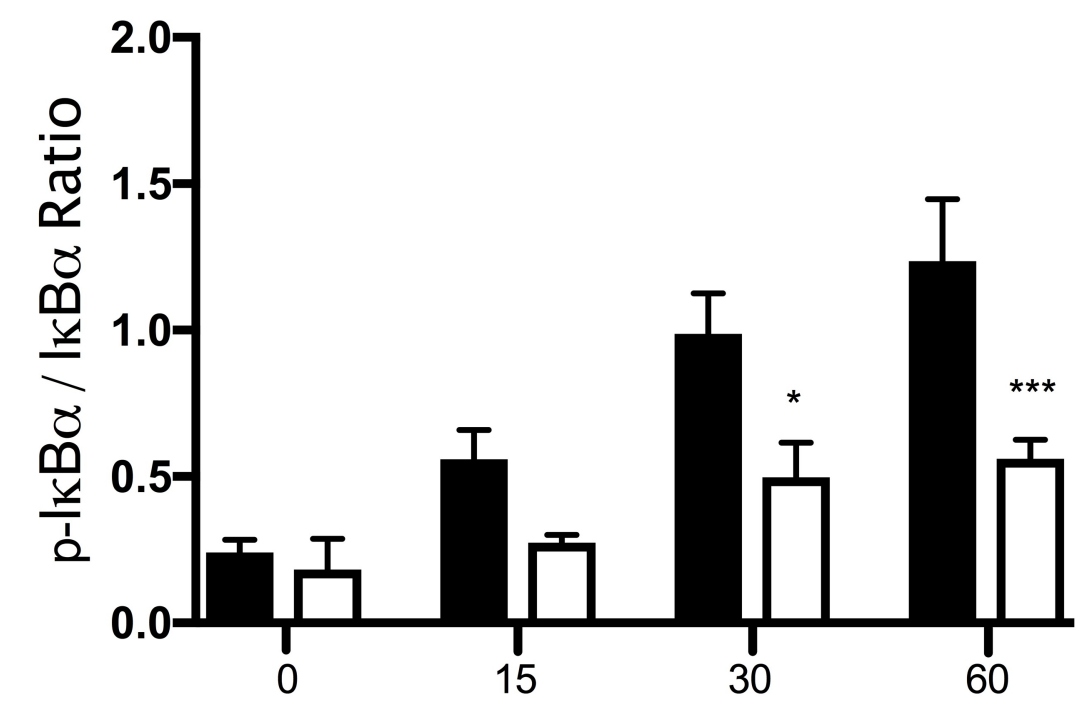

$p-\left.\right|_{\kappa} B \alpha$

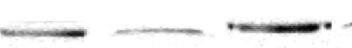

$\longrightarrow$

IкB $\alpha$

$\beta$-actin

D

p-38

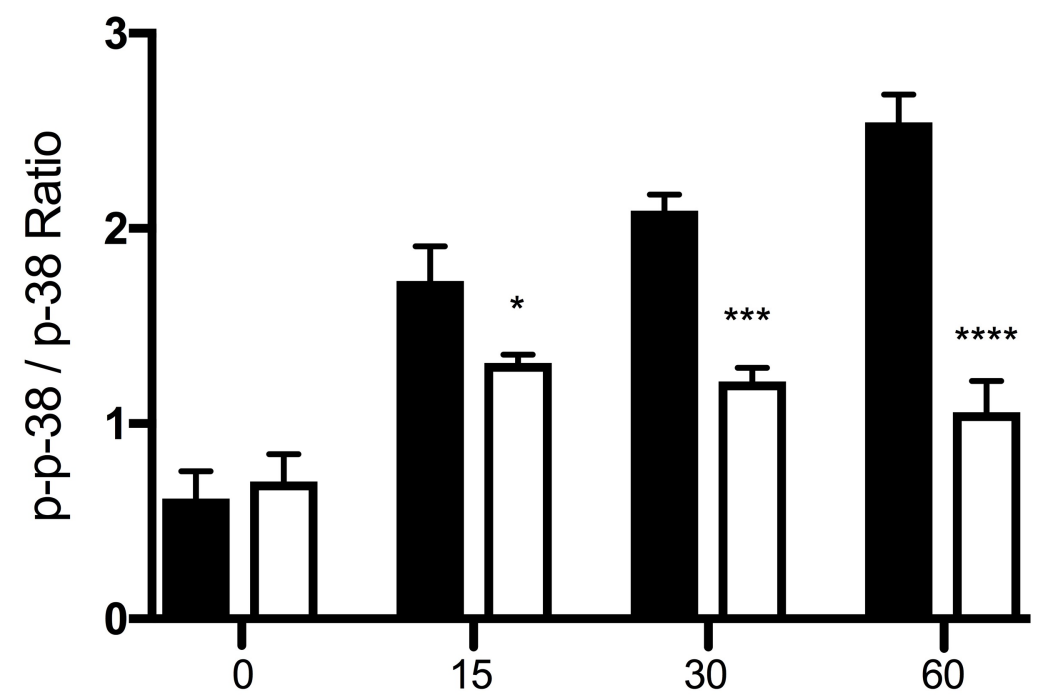

p-p-38

p-38
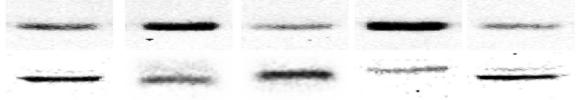

$\beta$-actin 